\title{
Applying networked learning to improve learner interactions: A new paradigm of teaching and learning in ODL
}

\author{
Tung Lai Cheng \\ Wawasan Open University, Malaysia
}

\begin{abstract}
Historically, much of online distance education has been plagued by issues such as a lack of participant interaction from learner-to-learner or learner-to-instructor. With the development of Web 2.0 and the recent emergence of social media sites, there are new opportunities for distance learners to practise 21st-century skills in collaboration, knowledge sharing and developing critical thinking. General interest regarding networked learning pedagogies has shifted to the use of social media tools as a replacement tool to enhance student learning in the Web 2.0 environment. The integration and use of social networking technology as a distance learning platform seems to hold promise for the distance learning mode. Many distance education institutions have traditionally employed a learning management platform (LMS), which in a broad sense does promote a certain exchange of information between learners. However, these platforms suffer from not performing in "real time" and are very much lesson-focused. In contrast, networked learning, which relies heavily on social networking media, can offer a better learning environment to students. The important feature is that it focuses on people (the learners) rather than simply the content, which, in turn, helps build a "learning community". This paper explores the pedagogical linkages between the networked learning approach and social networking media. A comprehensive technical literature review of the history of social media networking in the $O D L$ environment and the primary role and impact on ODL are discussed and analysed. This exploratory paper provides some insight into the strategies ODL institutions could adopt to better understand the new paradigm of teaching and learning in a networked world.
\end{abstract}

\section{Introduction}

The use of open and distance learning (ODL) as a primary instructional delivery mode has become popular in the past two decades and is expanding at an unprecedented rate. According to Allen and Seaman (2007), the growth rate in the number of learners who were enrolled in at least one online or distance learning course has significantly exceeded the growth rate of conventional brick-and-mortar classroom lectures. The growth of ODL as an alternative learning option is partly due to the globalisation and competitiveness of higher education, and the development of information and communication technologies (ICT) which have brought about a dramatic transformation in learning options, especially in the Asian region (Jung, 2009). The development of information and communication technologies, such as the 
Internet, has revolutionised the concept of information accessibility. As Wesch (2008) noted, the process of searching for, and finding, needed information a decade or so ago could be very time consuming, whereas today, with advanced information technologies, computers produce thousands of gigabytes of information in the blink of an eye. In addition, this information is networked, which further increases the amount of information produced for the end user. As information grows and becomes more accessible and easier to find, as Hicks and Graber (2010) noted, "knowledge is now decentralised, accessible and co-constructed among a broad base of users through discussion and participation in the Web 2.0 environment."

New technologies that influence how information is created, shared and connected holds promise for education, especially in the online distance education mode. Historically, much of online distance education has been plagued by issues such as learners' feelings of isolation, a lack of participant interaction from learner-to-learner and from learner-to-instructor. This can lead to higher dropout rates compared to conventional education (Veletsionos \& Navarrete, 2012).

Simultaneously, with the emergence of Web 2.0 technologies and the recent growth of social networking applications, distance learners have increasing opportunities to practise 21 st-century skills, specifically: collaboration, knowledge sharing and the development of critical thinking skills. As noted by Siemens and Conole (2011) “... the idea of the Internet - distributed, social, and networked - influences the structure of education, teaching, and learning." The authors observed that the emergence of new Internet technologies has changed how people communicate and interact with each other, and how they create and share content with each other. The implications for education are significant. The changing technology environment provides new opportunities for teaching and learning strategies focused on the use of online networked learning tools to create better, more functional learning communities.

General interest regarding networked learning pedagogies has shifted to the use of social media tools as a replacement tool for enhancing student learning. The integration and use of social networking technology as a distance learning platform seems to hold promise in the ODL mode that fits into the frame laid out by a number of researchers (Brady et al., 2010; Siemens \& Conole, 2011; Veletsionos \& Navarrete, 2012). Many distance education institutions have traditionally employed Learning Management System (LMS) platforms and/or Content (or Course) Management System (CMS) platforms. While, generally, LMS and CMS promote a certain amount of information exchange between learners, they suffer from the fact that they do not perform in "real time", lack the online social presence feature, and are very much lesson focused.

Networked learning and teaching strategies rely heavily on social media and focus on the use of online tools to create learning communities. They seem to do more than LMS or CMS with regards to student and instructor interactions - which, in turn, can enhance actual student academic achievement. The main feature of networked learning strategies is that they focus on people (the learners) rather than simply content, which encourages development of a "learning community". The objective of this paper is to explore the pedagogical linkages between a networked learning approach and social networking media in the ODL environment. 


\section{Networked learning: Alternative to teaching and learning}

What is networked learning? Education today is significantly different, in many ways, from what it was before the Internet. In the digital age, the traditional top-down, centre-out approach to education is beginning to gradually diminish, and looking back over time, many things have changed. Things like learner-generated content, informal interactions, short messages, and computer-mediated (nonverbal) interactions are the norm for current digital age learners (Wiske, 2011). The central question here for most educators and researchers is: To what extent can existing teaching and learning approaches support the needs of today's digital age and future learners?

Networked learning's emergence can be traced back to the late 1980s and 1990s, during the period of transition from the technologies of Web 1.0 to Web 2.0. The idea came into the spotlight when the concept of e-learning was introduced, and when collaborative applications such as content management systems and Blackboard, which encouraged interactions between learners, were developed. Harasim, Hiltz, Teles and Turoff (1995) wrote that future [networked] learners will have access to formal and informal education of their choice, and they will be boundary-less, actively participating in learning with, and from, experts and peers wherever they are located. This concept opens new opportunities and challenges for educators.

Networked, as the name implies, involves inter-connected nodes of information that are accessible from anywhere in the network, by anyone. Siemens (2004) noted that a network can simply be defined as "connections between entities". Examples such as computer networks, power grids, and social networks all function on the premise that people, groups, systems, nodes, and entities are inter-connected to create an integrated whole. There is a strong implication that networks are more than simply an aggregate of parts; they assume a place and acquire abilities that simple connections cannot provide - a network can grow and change, and can become a "sum" that is larger than its parts. Due to this emergent property, the author claims that alterations within the network may create ripple effects on the whole.

Although networked learning can be defined in numerous ways, including with and without the presence of communication technology tools, the definition put forward by the South Western Sydney Institute of Social Networking Wikispace (2011) is:

Networked Learning is a relatively new learning and teaching strategy which focuses on the use of online tools to create learning communities... Networked Learners establish an online identity and formulate relationships with other people to communicate and develop knowledge. The focus of Networked Learning strategies is on developing and maintaining connections between people and information to facilitate learning and collaboration.... can be used to facilitate both formal and informal teaching and learning, and provides opportunities for learners to develop their knowledge by sharing, communicating and collaborating with others sharing information with experts and other learners from other parts of the world. 
The Centre for Studies in Advanced Learning Technology (CSALT) Lancaster University (2004), a research group that focuses on the field of Technology Enhanced Learning (TEL) applied to adult education and training, defines networked learning as "learning in which [an] ICT tool is used to promote connections between one learner and other learners; between learners and tutors; between a learning community and its learning resources". The interactions between people can be synchronous, asynchronous, or can be through text, voice, graphics, video, shared workspaces or combinations of these forms. Lally (2000) offered that in the networked collaborative learning environment, the teacher provides new opportunities to understand the nature of teaching and learning, using mainly text as a basis for teaching and learning exchanges. This form of networked collaborative teaching and learning helps students acquire meaningful knowledge through shared, emergent goals and mutual construction of meaning. In addition, this strategy equips learners with valuable social skills for the workplace (Abdullah et al., 2011).

It seems that the main term in networked learning pedagogy is connections; networked learning is said to be closely associated with Connectivism Theory. Two educational theorists, George Siemens and Stephen Downes have explored learning in the networked digital age and addressed how learning occurs when it moves into informal, networked and technologyenabled environments. Siemens (2005) noted that learning is a process that occurs within a nebulous environment of shifting core elements and it is not entirely under the control of the individual. The process of learning concerns connecting specialised information sets and the networks that enable the individual to learn more than what they would otherwise know; the networks allow and promote greater learning. Siemens offers that the principles of networked learning are grounded to connectivism, which is shown in the following:

- Learning and knowledge rest in diversity of opinions.

- Learning is a process of connecting specialised nodes or information sources.

- Learning may reside in non-human appliances.

- Capacity to know more is more critical than what is currently known.

- Nurturing and maintaining connections are needed to facilitate continual learning.

- Ability to see connections between fields, ideas and concepts is a core skill.

- Currency of knowledge is the intent of all connectivist learning activities.

- Decision making is itself a learning process. Choosing what to learn and the meaning of incoming information is seen through the lens of a shifting reality. While there is a right answer now, it may be wrong tomorrow due to alternations in the information climate affecting the decision. 
Downes (2006) outlined his views on the Theory of Connectivism and asserts that learning and knowledge are distributive, that is, not located in any given place and therefore not "transferred", but rather consist of the network of connections formed from experience and interactions with a knowing/knowledge community. These new approaches to learning are based on conversation and interaction about sharing, creation and participation, and looking at learning not as a separate activity, but rather, as embedded in meaningful activities such as games or workflows. The author has included two graphics, which illustrate the differences between the traditional educational or "centralised" model, and the "distributed" networked learning paradigm. The difference between the traditional and distributed approaches may be observed in the following diagrams (Figure 1).

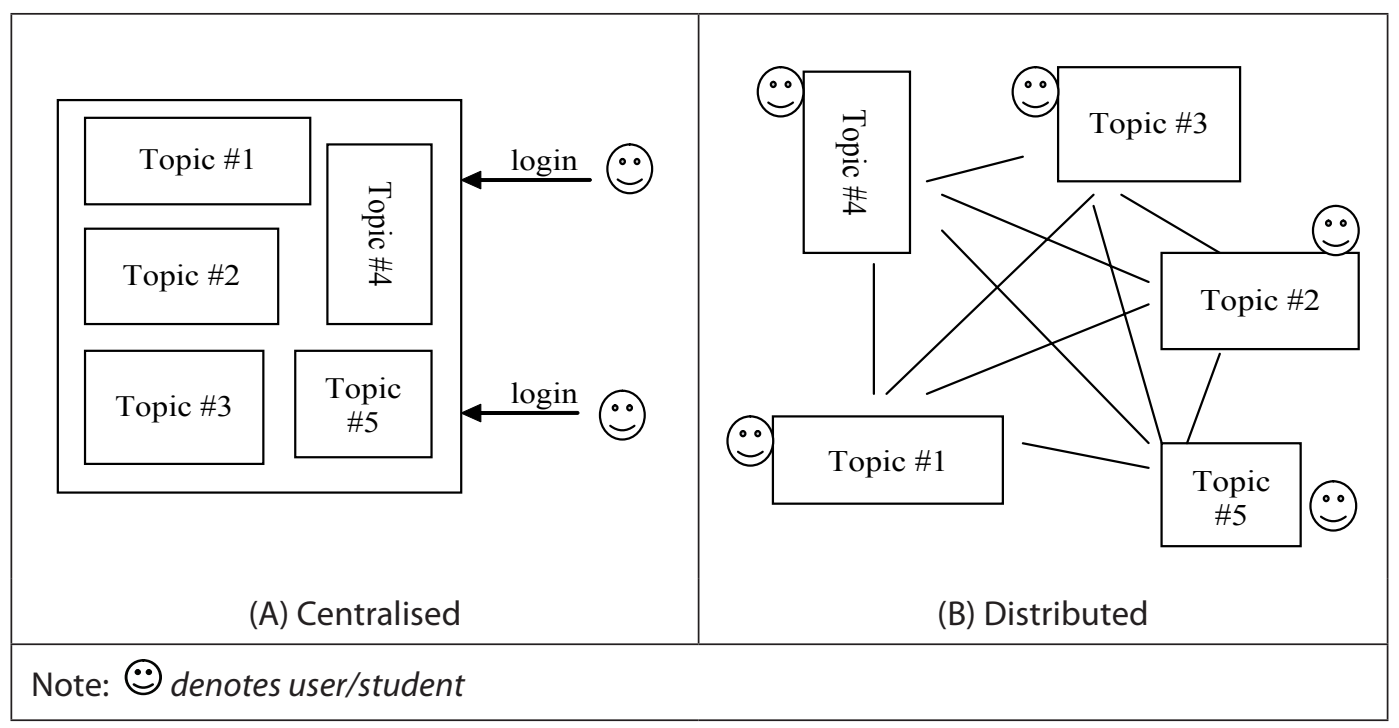

Figure 1 Centralised traditional learning approach (A) and distributed networked learning model (B)

\section{Networked learning: Applying it through the use of social networking media in teaching and learning}

While the networked learning theory is about connecting, and addresses learning when it moves into informal, networked and technology-enabled environments, it needs media to facilitate the connections. The use of open, networked tools, such as social networking media, can provide learners with the opportunity to engage in rich learning experiences. The impact of social networking media has been phenomenal; they have continued to gain prominence with both adult and teen users. Social networking media are online sites where users create and build their personal networks, enabling them to connect to other users either for personal or professional reasons. There are numerous social networking tools that are able to facilitate teaching and learning. Examples of social networking tools (SNT) that are currently popular among educators to facilitate teaching and learning according to their functionality are listed in Table 1. 


\begin{tabular}{|c|c|c|}
\hline SNT & Examples & Functionality \\
\hline Personal social sites & $\begin{array}{l}\text { Facebook, MySpace, Google+, } \\
\text { Yahoo 360, Hi5, Bebo, etc. }\end{array}$ & $\begin{array}{l}\text { Allow users to construct a public/ } \\
\text { semi-public profile, articulate } \\
\text { a list of other users (mainly for } \\
\text { personal reasons) that they share a } \\
\text { connection with, and view their list } \\
\text { of connections within the system. } \\
\text { A profile is generated from answers } \\
\text { to questions, such as age, location, } \\
\text { interests, etc. Some sites allow } \\
\text { users to upload personal pictures, } \\
\text { add multimedia content or modify } \\
\text { the look and feel of the profile and } \\
\text { personal theme. Many sites allow } \\
\text { users to post blog entries, search } \\
\text { for others with similar interests, and } \\
\text { compile and share lists of contacts. } \\
\text { User profiles often have a section } \\
\text { dedicated to comments from friends } \\
\text { and other users. }\end{array}$ \\
\hline Wiki sites & $\begin{array}{l}\text { WetPaint (Wikis in Education), } \\
\text { PBworks (formerly PBWiki), } \\
\text { Wikispaces (education), } \\
\text { TermWiki, Writely, etc. }\end{array}$ & $\begin{array}{l}\text { Provide users with opportunities } \\
\text { for information sharing and } \\
\text { collaboration in real-time } \\
\text { collaborative editing (RTCE). A Wiki } \\
\text { is a space on the Web where users } \\
\text { can share work, ideas, pictures, links, } \\
\text { video, and media - or anything } \\
\text { else for information sharing and } \\
\text { collaboration. }\end{array}$ \\
\hline Blogs & $\begin{array}{l}\text { Edublogs, Weblogg-ed, } \\
\text { Wordpress, TeachStreet, } \\
\text { LiveJournal, etc. }\end{array}$ & $\begin{array}{l}\text { Useful tools for information } \\
\text { sharing, personal reflection, and } \\
\text { collaboration. Blogs provide a } \\
\text { communication space in which } \\
\text { users can express opinions in the } \\
\text { form of a diary, journal, what's new } \\
\text { page, or links to other web sites. }\end{array}$ \\
\hline e-communication & $\begin{array}{l}\text { Skype, Gtalk, Eyejet, Nabble, } \\
\text { WizlQ, etc. }\end{array}$ & $\begin{array}{l}\text { Social networking tools that are } \\
\text { used primarily for communication } \\
\text { over theWeb. These communication } \\
\text { tools offer options for users or } \\
\text { groups to communicate with each } \\
\text { other either asynchronously and/ } \\
\text { or in real time. }\end{array}$ \\
\hline
\end{tabular}




\begin{tabular}{|c|c|c|}
\hline $\begin{array}{l}\text { e-communication } \\
\text { Professional } \\
\text { networking sites }\end{array}$ & $\begin{array}{l}\text { Linkedln, Ning for Teachers, } \\
\text { Elggs for educators, etc. }\end{array}$ & $\begin{array}{l}\text { Similar to personal social sites like } \\
\text { Facebook and MySpace but more } \\
\text { focused on business, education, and } \\
\text { professional points of view. Basically } \\
\text { works on the concept of multi-tiered } \\
\text { contacts (like Facebook) by which } \\
\text { registered users maintain a list of } \\
\text { business/professional contacts. } \\
\text { Professional site with information } \\
\text { strictly pertaining to vocational } \\
\text { interests. }\end{array}$ \\
\hline Photo/Video sharing & $\begin{array}{l}\text { Flicker, PhotoBucket, } \\
\text { YouTube, Vimeo, TeacherTube, } \\
\text { SWSiTube (only applicable } \\
\text { to South Western Sydney } \\
\text { Institute communities) }\end{array}$ & $\begin{array}{l}\text { One of the fastest growing online } \\
\text { activities that allows users to upload } \\
\text { photos and videos, publishing and } \\
\text { sharing with users from around } \\
\text { the world. These tools offer a rich } \\
\text { online experience that combines } \\
\text { video clips (movies), sound, images, } \\
\text { and text that increase information } \\
\text { sharing across the world. Some } \\
\text { may include options for forming } \\
\text { groups to facilitate sharing and } \\
\text { communities of practice. }\end{array}$ \\
\hline $\begin{array}{l}\text { Bookmarking and } \\
\text { tagging }\end{array}$ & Diigo, Del.icio.us, Furl, etc. & $\begin{array}{l}\text { Allow users to share, organise, search } \\
\text { and manage favourite websites. } \\
\text { With these tools, users can save } \\
\text { their favourite websites online and } \\
\text { can share them publicly or privately. }\end{array}$ \\
\hline $\begin{array}{l}\text { RSS (Rich Site } \\
\text { Summary) and } \\
\text { Syndication }\end{array}$ & Bloglines, Suprglu, etc. & $\begin{array}{l}\text { RSS is a format for delivering } \\
\text { regularly changing web content. It } \\
\text { allows users to easily stay informed } \\
\text { by retrieving the latest content from } \\
\text { sites without the need to subscribe } \\
\text { to each site's email newsletter. }\end{array}$ \\
\hline Virtual worlds & $\begin{array}{l}\text { Second Life (SL), Active } \\
\text { Worlds, Club Penguin and } \\
\text { WhyVille, etc. }\end{array}$ & $\begin{array}{l}\text { A simulation based on a virtual (3D) } \\
\text { world where users can socialise, } \\
\text { connect and create using voice and } \\
\text { text for chatting. }\end{array}$ \\
\hline Microblogging & $\begin{array}{l}\text { Twitter, Yammer, Moblog. } \\
\text { co.uk, Tumblr, Plurk, etc. }\end{array}$ & $\begin{array}{l}\text { This form of blogging has become } \\
\text { popular over the last few years. The } \\
\text { difference from a traditional blog } \\
\text { site is content posting. The content } \\
\text { posting is usually a short sentence } \\
\text { (i.e., update) or links (e.g., video, } \\
\text { links, images). }\end{array}$ \\
\hline
\end{tabular}

Table 1 Social networking tools (SNT) by functionality Source: Adapted from the Social Networking Toolbox site http://socialnetworking.swsi.wiki spaces.net/SocialNetworkingToolbox 
The impact of such social networking media on learning environments, especially when these are adapted to enhance the breadth and depth of information resources as well as the inter-connectivity between learners and lecturers, presents an opportunity for educators to keep learners engaged (Wankel, 2009). Thomas and Thomas (2012) contended that many institutions are often resistant to change and view these new networked technologies as a "young-person's game", which is to say, more of an obstacle than an opportunity. Institutions which choose to harness networking technologies will be championed for innovation compared to those who avoid these opportunities. Siemens (2010) in his personal blog argued that the social and technology networks might be seen by some as subverting the role of the teacher in teaching and learning, when in fact what it can help do is to make the "classroom walls thinner" or wall-less. Experts are no longer "out there" or "over there".

Social networking media such as Skype or WiZiQ bring virtually anyone from anywhere into a discussion forum or into a classroom, without them having to be physically present. Learners are freely interacting directly with researchers through Twitter, blogs, Facebook, and so on. In line with the popularity of these technologies, research re-purposing these technologies for educational activities in higher education and ODL is still quite fertile, as implementations are usually not large-scale or university-wide, and are mainly confined to a specific level of study. With that premise in mind, and drawing from the literature, the following case studies, which show the application of networked learning pedagogy via social networking media in higher institutions (either in distance or blended mode) are presented.

\section{My Westminster}

Oradini and Saunders (2008), two professors from the University of Westminster, England, presented an evaluation study of the use of a social networking site called My Westminster, powered by Elgg, that allows users to create their own profiles, upload photographs and documents, create and join discussion groups, send instant messages, publish blogs and presentations all in one single display.

The university has around 24,000 students, mainly engaged in face-to-face interactions, with minor distance learning courses available for working adults. The study covered all academic employees of the universities and students who accessed the system from September 2007 to January 2008. Both quantitative and qualitative data were collected via questionnaires, personal blog posts, and community forum posts. There were 3,048 registered users of My Westminster, with approximately 2,300 students and the rest were academic staff.

The results of the evaluation showed that student users, in particular, were split in their opinions about whether the system was useful or not. Some student users commented that the system is invaluable for making new friends and being connected to their peers and supporting each other, especially when a new semester begins. Other students felt it was helpful and liked it because it was a closed community, which they regarded as better than open public commercial social networking systems like Facebook or MySpace. For instance, students commented that the benefits of the closed system included having a university-owned social networking system 
that makes it easier to find help, such as where to go for educational assistance and inquiries. Others commented that although it appears to be both a formal and informal form of learning, it was seen as an educational space, where they have greater control, autonomy, and freedom.

Among students not in favour, most cited not having sufficient time and having too many systems for them to interact with, which might seem to them to be redundant, because some of them already used Facebook. Academic staff users mostly felt that the system had helped them and students to build a sense of community and belonging. Like student users, many faculty members felt that they had very little time to use the system. The authors also noted that clearly "one size does not fit all" when it comes to preferences, and Facebook can function in different ways depending on the preference of users and that seems to provide an important contribution to its popularity.

\section{Teaching an online education technology class via Elgg}

Veletsianos and Navarrete (2012) conducted an exploratory study to identify and understand learners' experiences in an online education technology course facilitated through a social networking platform, called Elgg, at the University of Texas at Austin, USA. The course ran for six weeks, and on each day the course instructor would introduce a new topic and students were asked to read, watch or listen to resources online, and then respond to selfreflective questions on their personal blogs (in the Elgg platform). All students were required to read their peers' reflections, post questions, and respond to all question/comments left on their blog. This process was continued and grades were given accordingly at the end of these activities. The authors explained that this process shaped participation and created space for student-centred interaction and discussion to take place.

Students' self-reflections about what they learned were shared among their peers with feedback, with occasional involvement from the instructor to direct students to particularly noteworthy comments and to learn from each other. Findings from this study indicated that students enjoyed and appreciated the social learning experience by supporting one another. Many students noted that their learning experience was enhanced through their interactions. However, one thing to note about this study was that students' participation was limited to course-related purposes and students did not seem to mix social and educational participation. They also seem to have required additional support to manage the expanded amount of information presented to them.

Though students indicated that networked learning opportunities are promising and cherished the opportunities for interaction, the authors also noted that some students seem to lack skills in managing their learning strategies, such as the ability to find and categorise content for future retrieval and to easily traverse networks of interest. This study also suggested that ongoing participation and collaboration within the context of a social network seemed to alleviate the issue of isolation and lack of support, which is especially important in the ODL environment. While this research only focuses on a small sample size (14 postgraduate students), it does offer insights and information for future larger population studies. 


\section{Ning as an educational e-learning tool}

Brady, Holcomb, and Smith (2010) explored the use of an alternative non-commercial educational-based social networking site, called Ning, by a group of postgraduate students enrolled in distance education courses at North Carolina State University, USA. Their study was designed to identify and examine students' perceptions of the benefits associated with using the Ning network, which was created specifically for the course. The sample was drawn from students enrolled in one fully asynchronous distance education instructional technology course and two blended (hybrid), synchronous distance education educational leadership preparation courses.

The primary use of Ning was as a discussion tool for students to share ideas and discuss topics covered in each of the courses. At the end of the semester, student participants were asked to complete an online survey asking about their attitudes towards Ning, towards a replacement of a Course Management System (CMS), such as Blackboard or Moodle, based on their semester worth of experiences. Findings from the study showed that the majority of student participants agreed that communication and collaboration were appreciably enhanced using Ning during their course of study. While the findings were supportive of the use of Ning in distance education, some student participants expressed a preference for face-to-face communications over the use of Ning. The authors explained that the reason for this may be because this was a new experience for some students, and they might simply prefer more familiar platforms like Blackboard or Moodle. Their findings further suggest that there is a need for effective training and support of the use of Ning in educational settings, for both students and faculty. The authors further commented that students seem to need more time than just one semester to feel comfortable and be part of the Ning "community".

\section{Facebook group as a learning management system}

In this study, a group of researchers (Wong et al., 2011) explored the use of a Facebook group as a replacement for an LMS, and the students' perceptions of using Facebook in two teacher education hybrid courses in Singapore. One course was offered to in-service school teachers and corporate sector employees who were pursuing their postgraduate degrees. Their ages ranged from 24 to 55 . The other course was an elective module for undergraduate students, aged between 20 and 23, who were majoring in various subjects.

The central contention of the authors was that Facebook offered key benefits from processbased learning as opposed to content-based learning (LMS). Furthermore, the functionality of LMS, such as putting up announcements, sharing resources, organising weekly tutorials, and conducting online discussions can all be performed just as well in Facebook.

The instructors for each course created a Facebook group before the course started. The activities were maintained and carried out in the Facebook group throughout the semester. To examine if the Facebook group members successfully used the platform as an LMS, the researchers conducted an online survey at the end of each course to find out students' experiences with regards to the pedagogical, social, and technological affordances of the Facebook group. 
The findings of this study confirmed that students were satisfied with the use of the Facebook group as an LMS and agreed that those using the new online learning platform (Facebook) were able to make announcements, share resources, take part in online discussions and participate in weekly activities just as well as when they were using an LMS. However, the findings also acknowledged certain limitations, such as that Facebook does not support learning resources in the PDF or PDT formats; hence, additional third-party tools like Google Docs were required. Also, there were no embedded survey features provided, unlike in an LMS, and most of all, features like threaded discussions were missing from this platform. Some older participants did not perceive Facebook as a safe environment for teaching and learning. Most of them were worried that their academic performance in the course could potentially be discovered by their social friends, or were concerned that information about their personal lives might be accessed by the instructors.

The researchers in this study noted that though Facebook has the potential to be used as an LMS because it enables students to easily communicate and interact with their peers and instructors, factors such as privacy, Internet safety and sound instructional design are a critical concern in the social learning environment.

\section{Lost in social space - Elgg experience for institutional learning}

Dron and Anderson (2009) conducted a study of an online undergraduate course, Development in Learning Technologies, taught via the Elgg platform at the University of Brighton, United Kingdom. Students enrolled were primarily majoring in computing and digital media programmes. Most students had previously experienced the Blackboard (CMS) environment as the primary communication channel between their peers and as a method of providing instruction before taking the course which employed the Elgg system.

The instructor created an Elgg-based community where the main tasks were posted for each week, much of the dialogue was achieved through blog comments, and students were required to maintain their own blogs, tagging entries relevant to the course. The instructor played a moderately active role through dialogue within the main community, email responses, realtime sessions and through comments on students' personal blogs.

According to the researchers, the findings suggested that students greatly enjoyed the amount of freedom that the Elgg platform provided, and that the networked learning experience was generally positive. Although some students found the workload was much higher and they had difficulties fitting into the self-directed working patterns called for in distance learning, the majority of the students found it highly rewarding. Another positive remark was that most students were found to have gone beyond the confines of the course requirements to explore and, occasionally, to contribute additional materials and ideas to the wider learning network. Since the authors themselves were the instructors of the course, they were able to note the changing social behaviour for two particularly shy students in the context of the social activities during the course because they were able to build a connected network of friends. 
While their findings revealed that most students' experiences were generally positive, some students found this mode too confusing and disorientating, and they reported a dislike for the Elgg interface. The researchers further commented that well over half of the students were active users of social networking sites such as Facebook, MySpace or Bebo prior to this course, and several mentioned that the Elgg interface seemed clunky and primitive by comparison. The final remark of the study was that some students were "lost in social space" and they needed additional support and scaffolding to participate in the social networked learning environment.

\section{Implications and future outlook of ODL}

The future learning landscape for ODL is being transformed and shaped by the ubiquitous networked applications, more digitalised communication devices, along with the ever-changing characteristics, needs and demands of students. Higher education and ODL institutions alike have begun seeing the potential benefits of tapping into socially based tools and Web 2.0 technologies. As discussed and shown in the previous section, most of the case studies indicated that students and instructors responded positively to the use of social networking technology as a distance learning platform.

Many distance education institutions have traditionally employed a learning management platform (LMS), such as Moodle, that enables the instructor to create online course content and post it on the Web without having to employ HTML or other programming languages. In a broad sense, an LMS does promote a certain exchange of information between learners (i.e., through forums, messaging, chats, etc.) for collaboration, but this suffers from not happening in "real time" and is very much lesson focused, that is, it lacks flexibility, a personal touch and networking capability. Take the example of an instructor who is using an LMS to pose questions in a static discussion forum, where students then post their responses, or vice versa; the reality is that the student posts are not community interactions at all; they are merely question and answer sessions.

The key difference between applying an LMS and social media tools is that the former is focused on lessons (or classes), rather than being user-centred; this is a change in focus which has the potential to increase student engagement. The premise is that social media tools focus on active participation in an online community, which extends learning beyond the boundaries of the learning one gains from simply reading the course materials. The focus of an LMS is on the documents (the information posted on the Web) and the learner usually cannot customise what they want to see. In contrast, social networking media can do more than an LMS. A comparison between typical features offered by an LMS and social networking media is presented in Table $\mathbf{2}$ to illustrate the key differences between them. 


\begin{tabular}{|l|c|c|}
\hline \multicolumn{1}{|c|}{ Features } & LMS (e.g., Moodle) & $\begin{array}{c}\text { Social networking media } \\
(\text { e.g., Elgg) }\end{array}$ \\
\hline Forum discussion & Yes $(\checkmark)$ & Yes $(\checkmark)$ \\
Wikis & No $(\mathbf{x})$ & Yes $(\checkmark)$ \\
Blogs & No $(\mathbf{x})$ & Yes $(\checkmark)$ \\
Chat & No $(\mathbf{x})$ & Yes $(\checkmark)$ \\
Photo/Video & Yes $(\checkmark)$ & Yes $(\checkmark)$ \\
Bookmarking & No $(\mathbf{x})$ & Yes $(\checkmark)$ \\
Tagging & No $(\mathbf{x})$ & Yes $(\checkmark)$ \\
& No $(\mathbf{x})$ & Yes $(\checkmark)$ \\
RSS & Yes $(\checkmark)$ & Yes $(\checkmark)$ \\
Messaging & No $(\mathbf{x})$ & Yes $(\checkmark)$ \\
Profile pages & No $(\mathbf{x})$ & Yes $(\checkmark)$ \\
File sharing & Yes $(\checkmark)$ & Yes $(\checkmark)$ \\
Calendar & & \\
\hline
\end{tabular}

Table 2 Comparison between an LMS and social networking media

Social media give learners greater control over the learning process and enable them to express themselves more easily. However, community-driven social networking media are not pre-loaded with traditional features such as grade-tracking systems, attendance systems and individual student activity reports, which academia normally require and which are available in LMSs. Nonetheless, all the above features are available via plug-ins, some at a nominal cost, and via integration work from the course creators. The integration and use of social networking media in teaching and learning via distance education seems promising, as noted in the EDUCAUSE Learning Initiative Horizon Report (2007): "the creation of social networking around academic topics provides instructors and students greater flexibility for teaching and learning, including the ability to join related groups by academic subject or discipline, comment on blog entries, view photos and videos, as well as countless instructional activities".

Dalsgaard and Paulsen (2009) argue that social networking media provide a unique feature transparency - that an LMS might not be able to offer. Transparency is said to be a unique feature of social networking services and according to the authors, transparency affords learners insight into each other's actions, ideas, backgrounds, understanding and contexts, which are critically important for creating the conditions under which learners will volunteer their ideas and can productively cooperate with each other in contributing to learning activities. Similarly, Poellhuber and Anderson (2011) noted that:

"The potential of synchronous web conferencing systems and of social software to convey transparency .... offer new avenues for student learning and support systems in distance education. In summary, we believe these tools hold strong theoretical promise to support interventions designed to improve learning, increase student engagement, and alleviate the high dropout rates traditionally observed in distance education." 
Additionally, Correia and Davis (2008) noted that in distance education, learners need a venue to connect and actively engage with other members of the class, who they never meet in person, and that activity in distance education courses needs to allow learners to apply their learning in an authentic educational context. DeSchryver et al. (2009) argue that in distance education courses, a mutually beneficial relationship seems to exist between social presence and participation in online discussions where learners with higher social presence tend to be more involved and engaged in conversations, which is what most distance education institutions would like to encourage among all students. According to Anderson (2005), social networking media tools might be the "killer app" for distance education, given their ability to enhance social presence, which has been found to be one of the most significant factors promoting a sense of community in online courses. Social presence, as the term suggests, is defined as "...the notion that a sense of presence can be conveyed through technology" (Poellhuber \& Anderson, 2011).

McLoughlin and Lee (2010) stated that the rethinking of teaching and learning pedagogy in the world we live in today is highly incongruent with the previous century, and institutions must recognise this. Today's world is characterised by social mobility where individuals are expected to have multiple career paths or become engaged in learning and re-skilling throughout their lifespan. The authors offered that in the field of distance education there is a need to reconsider the notion of pedagogy so that learners are seen as active participants and co-producers of learning resources rather than passive consumers of content.

Hamid, Chang, and Kurnia (2009) suggest that the future of learning is likely to be even more digital, more connected, more social and more personalised. Furthermore, distance education and higher education deal with users who often label themselves "digital natives" and "digital immigrants". These groups perceive themselves to be familiar with social networking media and Web 2.0 technologies in their day-to-day life. However, the authors did offer the suggestion that careful planning must be made prior to the adoption of this form of social networking technologies because, as the authors noted, "...not all digital natives are keen to have such technologies for various reasons [including]: diversity of experiences, familiarity, attitudes and expectations towards technologies". In fact, in this respect, in a study conducted by Poelhuber and Anderson (2011), it was shown that the younger group of subjects (16-24 years old) distinguishes itself from other age groups not by revealing an increased desire to use social media, but rather a decreased one. In other words, older groups seem to see the pedagogical potential of social media more than younger ones do, even if the older ones are less experienced in using these types of media. The explanation from the researchers was that those "digital natives" who use social media mostly outside of an educational context and for non-educational purposes, do not necessarily see them as tools for learning. This seems to be particularly true for social networking, which a fairly large number of experienced users are not interested in using for learning purposes. On the other hand, the researchers noted that the older groups of learners are typically the ones who have more experience in distance learning but are also the ones who value the potential these tools might offer or, at least, are more interested in using them for learning. 
Cao and Hong (2011) commented that applying social media in higher education teaching and learning needs research attention. They pointed out that there are essentially four key antecedents that influence social media utilisation in teaching and learning. The researchers suggested that the first step in building a social media friendly teaching environment is to assess the level of readiness at the department/institution level. Readiness is defined in the forms of "self-efficacy" and "compatibility", which are said to be two important elements in intention and actual social media adoption in teaching and learning. Secondly, the researchers noted that the adoption of social media in learning is likely to succeed, if instructors have both an internal and external support system from their immediate departments or from the institution as a whole. Part of the support system may come from the learners (students) themselves, from among the instructor's community, or where the institution's stakeholders agree to address the need to adopt the social networking media for the good of teaching and learning. The third factor influencing intention and actual adoption is the perceived usefulness of social media for teaching. As social media are "user-centric", the types of usefulness mentioned concern student satisfaction and student learning outcomes, through collaboration, participation and sharing. The last and the fourth antecedent, according to the researchers, is the "perceived risks" associated with adoption, as time, resources, privacy and security may be major concerns. In short, the new teaching and learning paradigm of networked learning provides a new direction in which further studies can explore the impact of networked learning in the ODL environment. In spite of the potential and challenges outlined above, this paradigm offers a new learning pedagogy that stresses the combination of connections, especially in concert with person to person contact, that provides the most powerful teaching and learning potential.

\section{Conclusion}

In conclusion, the networked learning approach in teaching and learning, empowered by social networking media, can perhaps lead to a powerful paradigm shift in distance education. The changes have come about gradually, but the development of Web 2.0 technologies that enable the support of a social presence and which can potentially improve interaction and participation among distance learners is the new trend in teaching and learning. Hick and Graber (2010) note that we need to look beyond the "technolust" and the focus on using technology to start engaging more with the implicit societal changes that are happening by introducing the "five Cs" to participants. The researchers' offer that distance learners need to develop a sense of community, be able to collaborate among their peers, develop creativity, develop conversation to combat the sense of loneliness, and finally, develop a sense of control during the course of their learning process. This new form of technology challenges us, the ODL educators and enthusiasts alike, to rethink the creation and development of information and knowledge based on technological and sociological changes to meet the needs of distance learners. 
The new learning and teaching strategy, which focuses on the use of social and digital technology tools to create learning communities, such as networked learning, has changed the way students learn and interact with each other to gain knowledge. The untold beauty of incorporating social media tools into networked learning is that the flexibility and immediacy makes this form of teaching and learning more appealing to present-day learners, both the "digital natives" and the "digital immigrants". The incoming learners are people who might have become accustomed to social media as they may well already communicate often using social media and learn in a different way than the previous generations. Thomas and Thomas (2011) noted that "teaching methods and styles adopted previously are likely to be outmoded... recognising that social media is a requirement for modern-day business." The authors also posited that future research about facilitating future learners is likely to focus on the impact of social media beyond the immediate learning environment. New technologies brought about by the invention of Web 2.0 technologies and social networking applications seem to have given distance learners opportunities to practise 21st-century skills in collaboration, knowledge sharing and developing critical thinking skills (Siemens, 2010). The fact is that social networking has revolutionised teaching and learning. For instance, social networked learning has changed the way learners make choices in learning about the five Ws (who, what, where, when, and why) of programmes/courses they might want to study or might take. Learners may already be ready to be presented with the opportunity to develop relationships with like-minded learners, virtually, and create communities of sharing and learning.

As the case studies and literature review suggested, a shift of paradigm is happening in terms of technology's impacts on teaching and learning, and this shift goes beyond the more common arguments related to massive user-generated and expert content proliferating on the Web. As Hoffman (2010) stated, "The potential for loosening institutional controls over tool access, the rapid growth of social networking beyond college walls, and the decreasing costs for user training and ready-availability are suggestive that these new tools will spread like earlier innovations such as word processing and email as foundational tools for higher education." These new tools allow greater flexibility in designing environments rather than being stuck with content-focused containers, which creates an environment that can foster better and more personalised learning, ideal for distance learners. These new decentralised paradigms are likely to have a feedback effect on organisational structures related to technology because social networking learning has the potential to reinforce the power from the bottom-up, as learning will become even more based upon pedagogical needs instead of having only an institutional/administrative focus. It is perhaps the right time and perfect opportunity for all ODL institutions to seriously look into the power of networked learning - a new paradigm in teaching and learning.

Dr Tung Lai Cheng (email:lctung@wou.edu.my) is with the School of Business and Administration, Wawasan Open University, Penang. 


\section{References}

Abdullah, A., Embi, M.A., \& Nordin, N. (2011). The role of students in the development of a collaborative learning community through networked learning: A Malaysian perspective. The International Journal of Learning, 18(1), 347-360.

Allen, I. E., \& Seaman, J. (2007). Online nation: Five years of growth in online learning. Needhan, MA: Sloan Consortium.

Anderson, T. (2005). Distance learning - Social software's killer app? Retrieved from http:// auspace.athabascau.ca/handle/2149/2328 on 17 July 2012.

Brady, K. P., Holcomb, L. B., \& Smith, B. V. (2010). The use of alternative social networking sites in higher educational settings: A case study of the e-learning benefits of Ning in education. Journal of Interactive Online Learning, 9(2), 151-170.

Cao, Y., \& Hong, P. (2011). Antecedents and consequences of social media utilization in college teaching: A proposed model with mixed-methods investigation. On the Horizon, 19(4), $297-306$.

Conway, M. (2011). Book review: Educating educators with social media. On the Horizon, $19(4), 350-354$.

Correia, A., \& Davis, N. (2008). Intersecting communities of practice in distance education: The program team and the online course community. Distance Education, 29(3), 289-306.

Dalsgaard, C., \& Paulsen, M. (2009). Transparency in cooperative online education. International Review of Research in Open and Distance Learning, 10(3). Retrieved from http// www.irrodl.org/index.php/irrodl/article/view/671/1267 on 17 July 2012.

Dawley, L. (2009). Social network knowledge construction: Emerging virtual world pedagogy. On the Horizon, 17(2), 109-121.

DeSchryver, M., Mishra, P., Koehler, M., \& Francis, A.P. (2009). Moodle vs. Facebook: Does using Facebook for discussions in an online course enhance perceived social presence and student interaction? Proceedings from The Society for Information Technology and Teacher Education International, 329-336.

Dron, J., \& Anderson, T. (2009). Lost in social space: Information retrieval issues in Web 1.5. Journal of Digital Information, 10(2), 1-12.

EDUCAUSE Learning Initiative. (2007). The Horizon Report, NMC 2007 Higher Ed. Retrieved from http://www.nmc/publications/2007/report on 18 July 2012. 
Hamid, S., Chang, S., \& Kurnia, S. (2009). Identifying the use of online social networking in higher education. Retrieved from http://www. ascilite.org.au/conferences/auckland09/procs/ hamid-poster.pdf on 18 July 2012.

Harasim, L., Hiltz, S. R., Teles, L., \& Turoff, M. (1995). Learning networks: A field guide to teaching and learning. Cambridge, MA: MIT Press.

Hicks, A., \& Graber, A. (2010). Shifting paradigms: Teaching, learning and Web 2.0. Reference Services Review, 39(4), 621-633.

Hoffman, E. (2010). Social media and learning environments: Shifting perspectives on the Locus of Control. Retrieved from http://www.ineducation.ca/article/Social-media-andlearning-environments-shifting-perspectives-on-the-locus-of-control on 20 July 2012.

Jung, I. (2009). Changing faces of open and distance learning in Asia. The International Review of Research in Open And Distance Learning, 8(1). Retrieved from http://www.irrodl.org/index. php/irrodl/article/view/418/773 on 1 July 2012.

Lally, V. (2000). Analysing teaching and learning interactions in a networked collaborative learning environment: Issues and work in progress. Education-line. Retrieved from http:// www.leeds.ac.uk/educol/documents/00001648.htm on 4 July 2012.

Lancaster University, Centre for Studies in Advanced Learning Technology (CSALT) (May 2004). Definition of networked learning. Networked learning in Higher Education. Retrieved from http://csalt.lancs.ac.uk/jisc/definition.htm on 4 July 2012.

McLoughin, C., \& Lee, M. J. (2010). Personalised and self-regulated learning in the Web 2.0 era: Internalised exemplars of innovative pedagogy using social software. Australasian Journal of Education Technology. 26(1), 28-43.

Oradini, F., \& Saunders, G. (2008). The use of social networking by students and staff in higher education. Paper presented at the iLearning Forum, 2008 in Paris. Retrieved from http://www.eife-I.org/publications/proceedings/ilf08/contributions/improving-quality-oflearning-with-technologies/Oradini.pdf on 17 July 2012.

Poellhuber, B., \& Anderson, T. (2011). Distance students' readiness for social media and collaboration. The International Review of Research in Open and Distance Learning. Retrieved from http://www.irrodl.org/index.php/irrodl/article/view/1018/1960 on 27 July 2012.

Siemens, G. (2004). Connectivism: A learning theory for the digital age. elearnspace. Retrieved from http://www.elearnspace.org/Articles/connectivism.htm on 4 July 2012.

Siemens, G. (2005). Connectivism: Learning as network-creation. elearnspace. Retrieved from http://www.elearnspace.org/Articles/networks.htm on 4 July 2012. 
Siemens, G. (2010). Connectivism. Retrieved from http://www.connectivism.ca/?p=220 on 11 July 2012.

Siemens, G., \& Conole, G. (2011). Special issue - Connectivism: Design and delivery of social networked learning. The International Review of Research in Open and Distance Learning, 12(3), i-iv.

Thomas, M., \& Thomas, H. (2012). Using new social media and Web 2.0 technologies in business school teaching and learning. Journal of Management Development, 31(4), 358-367.

Veletsianos, G., \& Navarrete, C. (2012). Online social networks as formal learning environments: Learner experiences and activities. The International Review of Research in Open and Distance Learning, 13(1), 144-166.

Wang, Q., Woo, H., Quek, C., Yang, Q., \& Liu, M. (2011). Using the Facebook group as a learning management system: An exploratory study. British Journal of Educational Technology, 43(3), $428-438$.

Wankel (2009). Management education using social media. Organisation Management Journal, 6(6), $251-262$.

Wesch, M. (2009). From knowledgeable to knowledge-able: Learning in new media environments. Academic Commons. Retrieved from http://www.acAdemiccommons.org/ commons/essay/knowledge-knowledge-able on 2 July 2012.

Wiske, M.S. (2011). Unleashing the power of networked learning. Harvard Business Review, Retrieved from http://blogs.hbr.org/innovations-in-education/2011/03/how-do-we-unleashthe-html on 3 July 2012. 